\title{
Tide pools diversity in Bojonglarang-Jayanti Nature Reserve, West Java, Indonesia
}

\author{
TRI DEWI KUSUMANINGRUM PRIBADI", AUFA AULIA KANZA \\ ${ }^{1}$ Department of Biology, Faculty of Mathematics and Natural Sciences, Universitas Padjadjaran . Jl. Raya Bandung-Sumedang km.21 Jatinangor 45363, \\ West Java, Indonesia. Tel./Fax. +62-22-7796412, ”email: tridewi.pribadi@unpad.ac.id
}

Manuscript received: 1 July 2016. Revision accepted: 30 June 2017.

\begin{abstract}
Pribadi TWK, Kanza AA. 2017. Tide pools diversity in Bojonglarang-Jayanti Nature Reserve, West Java, Indonesia. Ocean Life 1: 43-48. Tide pools are micro-ecosystem in the intertidal zone, which have unique characteristics such as extreme water temperature range. Organisms living in it can survive by adapting to these extreme conditions. Study on community structure of macroinvertebrate in tide pools and along with the influencing environmental conditions has been carried out to observe species that can survive in such extreme conditions. Quantitatively, descriptive study on biotic and abiotic parameters was done by observing the tide pools, which passed 500-meter transect line parallel to the shoreline. Analyses of the biotic parameters included varied species, dominant species, species richness, species diversity index, dominance index, important value index, and macroalgal coverage. The observed abiotic parameters comprised water and air temperature, light intensities, conductivity, salinity, depth of tide pools in low tide conditions, extensive of tide pools, $\mathrm{pH}$, and DO (Dissolved Oxygen). Results in physical parameter measurements showed that the water temperature, light intensity, and conductivity were at the high category, while air temperature, salinity, and depth of water were in the normal category. The results showed 31 species of macroinvertebrate of 21 families and 6 classes, with the highest relative abundance on Ophionereis dubia by 0.56 . Macroalgal was dominated by Sargassum polycystum with $7.62 \%$ coverage. Species Diversity Index of macroinvertebrate was 2.53, with Dominance Index 0.85 . These indexes indicated the dominance of particular macroinvertebrate species, which have the tendency to be adaptive to extreme water temperature range.
\end{abstract}

Keywords: Batu Kukumbung, diversity, tide pools.

\section{INTRODUCTION}

As a micro-ecosystem in the intertidal zone, tide pool is an interesting habitat due to its high biodiversity and dense populations in a relatively small area. It is specific microecocosystems in the rocky intertidal zone and a natural habitat for organisms with wide environmental range, including temperature with the range of up to $15^{\circ} \mathrm{C}$ (King, 2009). Tidal cycles cause living organisms to be able to adapt to environmental conditions with extreme ranges like temperature, light intensity, and also the nutrients concentration.

There has been growing concern about the effect of global warming on species distribution, and former studies have suggested climate-driven species distribution shift both in terrestrial and marine (Hawkins et al. 2009). However, few studies have focused on the mechanical processes involved in species range shift. It remains largely unexplored, thereby limiting the capacity of ecologists to predict ecological alteration in terms of species adaptability.

The composition, abundance, and distribution of macroinvertebrate can be influenced by water quality. The disruption to the environment associated with climate change (e.g., coastal eutrophication, an increase in UV light) can affect Cecil organisms such as macroinvertebrate in tide pools in terms of biochemistry, ecophysiology, morphology, and the population level (Celis-Plá et al. 2015). The abundance of macroinvertebrate, which relatively settled at the bottom of the water column especially in intertidal zone, is very important in correlation to the food chain. Ecological excessive pressure can reduce the abundance of these organisms therefore it can disrupt the ecosystems as a whole.

Macroinvertebrate community structure in microecosystem tide pools at the coastline of Batu Kukumbung needs to be studied due to the ecological functions of the coastline as part of the Nature Reserve Bojonglarang-Jayanti. Therefore, studying the influence to determine the community structure inside tide pools and environmental conditions is needed to give further comprehension to the adaptability of species to environmental pressure.

\section{MATERIALS AND METHODS}

\section{Study area}

The location of the study was in Batu Kukumbung coastline, Bojonglarang-Jayanti Nature Reserve, West Java, Indonesia (107 $\left.24^{\prime} \mathrm{E} ; 7^{\circ} 30^{\prime} \mathrm{S}\right)$ (Figure 1). 

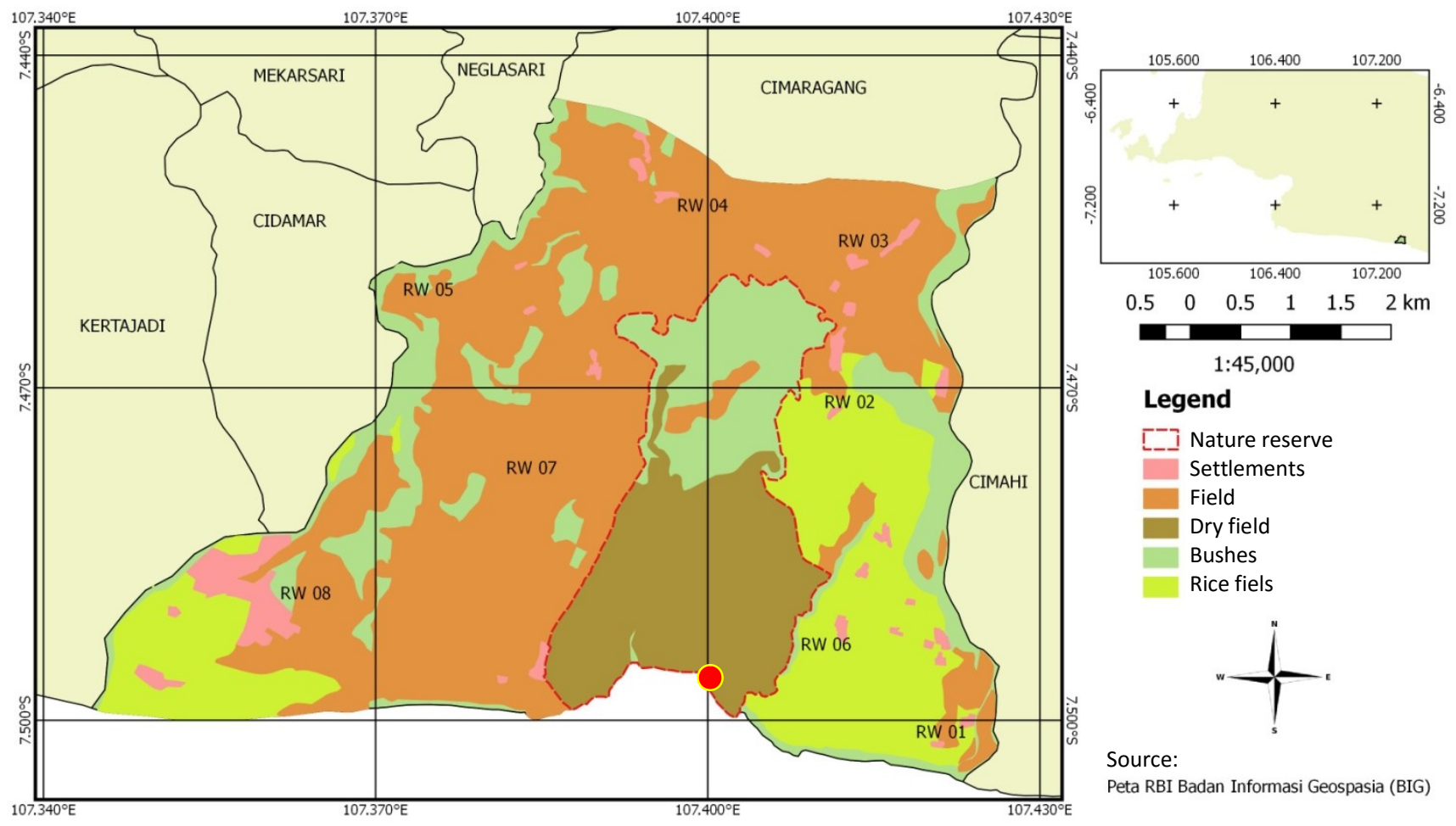

Source:

Peta RBI Badan Informasi Geospasia (BIG)

Figure 1. Location of the study site is in Batu Kukumbung coastline ( , Bojonglarang-Jayanti Nature Reserve, West Java, Indonesia

\section{Procedures}

Data were collected for 10 days in May 2015. Sampling was done during low tide within a specified time of the tidal prediction from Geospatial Information Agency. Collection of samples used survey methods by setting 500meter long transects parallel to the shoreline. Measurements were done for the abiotic and biotic parameters at each tide pool that passed by the transect line. Abiotic parameters included extent and depth of tide pool, air and water temperature, light intensities (Lutron LX100, Taiwan) pH, DO (Dissolved Oxygen), salinity, and conductivity (Eutech Cyberscan, Singapore) while biotic parameters were macroinvertebrate and other organisms in the tide pools.

The macroinvertebrate data were taken with survey sampling method which was modified from Welch (1948) with a $1 \times 1 \mathrm{~m}^{2}$ plot transect with the grid of $10 \times 10 \mathrm{~cm}^{2}$. Samples taken for identification were stored in a labeled plastic bag and given $4 \%$ formalin. Identification was done in the laboratory using identification book of Dharma (2005).

\section{Data analyses}

Index of species richness was measured using the formula created by Margalef (1968). Species abundance of macroinvertebrate is defined as the number of individual of a species in a plot per square meter. The abundance of species was measured using the formula by Brower and Zar (1977). The species diversity of tide pools was measured using Shannon-Wiener's formula (1949). Index of dominance was expressed by Simpson's Index (Odum, 1971), therefore it was executed by calculating Simpson's Diversity Index (Simpson, 1949).

The macroalgal coverage was measured using formula by Saito and Atobe (1970) in English et al. (1994) which has already been modified, with plot transect of $100 \times 100$ $\mathrm{cm}^{2}$ and grid of $10 \times 10 \mathrm{~cm}^{2}$.

\section{RESULTS AND DISCUSSION}

\section{Abiotic parameters}

This study also measured the abiotic factors in the tide pools during observation to have good comprehension of the interaction of abiotic and biotic factors. (Table 1).

Table 1. The abiotic parameter of tide pools in Batu Kukumbung coastline, Bojonglarang-Jayanti Nature Reserve, West Java, Indonesia

\begin{tabular}{lll}
\hline Parameter & Unit & Range Value \\
\hline Extent of Tidepool & $\mathrm{m}^{2}$ & $0.84-121.3$ \\
Water temperature & ${ }^{\circ} \mathrm{C}$ & $20.5-39.5$ \\
Depths & $\mathrm{cm}$ & $18-39$ \\
Salinity & $\%$ o & $24-35$ \\
Light Intensities & $\mathrm{lux}$ & $22,163-169,200$ \\
$\mathrm{pH}$ & - & $7-8$ \\
DO & $\mathrm{mg} / \mathrm{L}$ & $8.32-12.8$ \\
\hline
\end{tabular}


Table 2. The composition of the existing species and relative abundance of macroinvertebrate in the tide pools of Batu Kukumbung, Bojonglarang-Jayanti Nature Reserve, West Java, Indonesia

\begin{tabular}{|c|c|}
\hline Species & $\begin{array}{c}\text { Relative } \\
\text { abundance }\end{array}$ \\
\hline Anachis terpsichore G.B. Sowerby II (1822) & 0.03 \\
\hline Barbatia bistrigata Dunker (1866) & 0.01 \\
\hline Cellana radiata Born (1778) & 0.06 \\
\hline Chiton glaucus Boyle (1970) & 0.05 \\
\hline Ciboticola lunata Hedley (1902) & 0.01 \\
\hline Clypeomorus subbrevicula Oöstingh (1925) & 0.04 \\
\hline Clypeomorus bifasciata Houbrick (1985) & 0.01 \\
\hline Conus ebraeus Linnaeus (1758) & 0.02 \\
\hline Conus glaucus Linnaeus (1758) & 0.03 \\
\hline Drupella cornus Röding (1798) & 0.09 \\
\hline Euplica varians G.B. Sowerby II (1832) & 0.02 \\
\hline Gyrineum natator var. Robusta Fulton (1936) & 0.02 \\
\hline Loxorhynchus grandis Stimpson (1857) & 0.01 \\
\hline Marcia hiantina Lamarck (1818) & 0.01 \\
\hline Mitra litterata Lamarck (1811) & 0.02 \\
\hline Morula anaxeres Kiener (1836) & 0.01 \\
\hline Morula funiculata Reeve (1846) & 0.04 \\
\hline Morula granulata Duclos (1832) & 0.02 \\
\hline Nerita albicilla Linnaeus (1758) & 0.02 \\
\hline Ophiocoma echinata Lamarck (1816) & 0.18 \\
\hline Ophiocoma scolopendrina Lamarck (1816) & 0.08 \\
\hline Ophionereis dubia Müller \& Troschel (1842) & 0.56 \\
\hline Ophiothrix fragilis Abilgaard (1789) & 0.06 \\
\hline Pagurus anachoretus Risso (1827) & 0.15 \\
\hline Patella ferruginea Gmelin (1791) & 0.02 \\
\hline Pseudostomatella papyracea Gmelin (1791) & 0.01 \\
\hline Pyrene decussata Röding (1798) & 0.01 \\
\hline Semiricinula fusca Küster (1862) & 0.24 \\
\hline Semiricinula marginatra Blainville (1832) & 0.01 \\
\hline Siphonaria sirius Plisbry (1894) & 0.01 \\
\hline Stomopneustes variolaris Lamarck (1816) & 0.01 \\
\hline
\end{tabular}

During the observation, the water temperature in the tide pools being observed had a wide range and reached $19^{\circ} \mathrm{C}$. Light intensities showed a wide range of 23,600 lux to 169,200 lux. This wide range was probably due to the duration of the observation that occupied for 4 hours on average during low tide ( 7 a.m. to 11 a.m.). The depth of tide pools was shallow, ranging from $18-39 \mathrm{~cm}$. Other physicochemical parameters of water in the tide pools were still in the range of the limits that sustain life, including the DO that showed high value.

\section{Biotic parameters}

In this study, the tide pools in Batu Kukumbung showed a total amount of 31 species of macroinvertebrate. They were of 21 families and 6 classes consisting of Polyplacophora, Gastropods, Bivalves (phylum Mollusca), Echinoidea, Ophiuroidea (phylum Echinodermata), and Malacostraca (phylum Arthropoda, sub crustaceans). The species composition and relative abundance of macroinvertebrate in the observed tide pools can be seen in Table 2.

The results showed that the highest number of the class found in the tidepool was Gastropods with 20 species. The three most abundant species were Ophionereis dubia, Semiricinula fusca, and Ophiocoma echinata, respectively. The highest abundance was Ophionereis dubia with 0.56 . This value showed that Ophionereis dubia was the most abundant species and had a significant role in the tide pools at Batu Kukumbung.

Result also showed that Ophiocoma echinata, Semiricinula fusca, and Ophionereis dubia dominated the community with more than $80 \%$ of all species. Interesting result, however, was showed by the abundance of species present among classes (Figure 3) Although Gastropods was the highest in species richness, there was no abundance for it as the result. Among classes, Ophiuridae was the most abundant in tide pools of Batu Kukumbung (Figure 2).

In the tide pools, we also found other biotas such as fish, macroalgae, and coral (Table 3 and 4). Some individual fishes were trapped in the tide pools during low tide and identified during observation. There were also some species of macroalgae, dominated by brown macroalgae, Sargassum polycystum, and Padina boryana. Results of macroalgae coverage showed that dominant species was Sargassum polycystum with $9.62 \%$ coverage from all observed tide pools, with the occurrence frequency of up to $73 \%$.

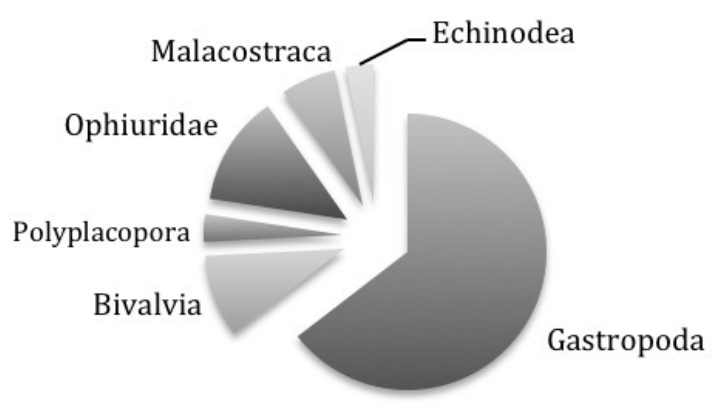

Figure 2. The composition of species richness among classes of macroinvertebrate in tide pools of Batu Kukumbung, Bojonglarang-Jayanti Nature Reserve, West Java, Indonesia

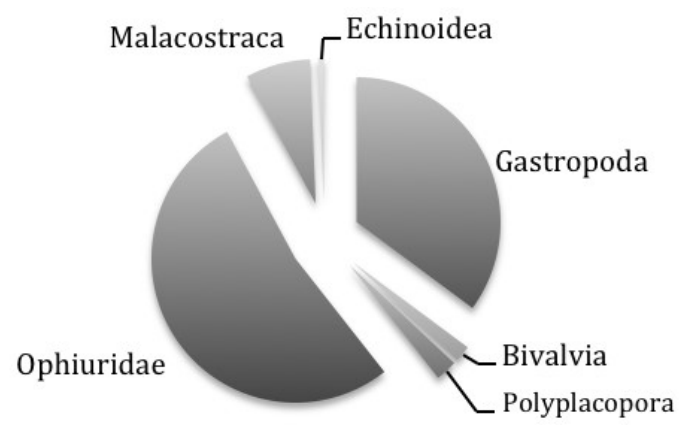

Figure 3. The composition of species abundance (individual $/ \mathrm{m}^{2}$ ) among classes of macroinvertebrate in tide pools of Batu Kukumbung, Bojonglarang-Jayanti Nature Reserve, West Java, Indonesia 
Table 3. Macroalgae and other biota in the Batu Kukumbung Tidepools, Bojonglarang-Jayanti Nature Reserve, West Java, Indonesia

\begin{tabular}{ll}
\hline Species & $\begin{array}{l}\text { Coverage } \\
\text { (\%) }\end{array}$ \\
\hline Boergesenia forbesii (Harvey) Feldman (1938) & $0.05 \%$ \\
Gracilaria gigas Harvey (1860) & $0.01 \%$ \\
Gracilaria verrucosa (Hudson) Papenfuss (1950) & $0.04 \%$ \\
Gracilaria coronopifolia J. Agardh (1852) & $0.06 \%$ \\
Padina boryana Thivy (1966) & $7.08 \%$ \\
Sargassum polycystum C. Agardh (1824) & $9.62 \%$ \\
Turbinaria ornata (Turner) J. Agardh (1848) & $0.01 \%$ \\
Ulva clathrata (Roth) C. Agardh (1811) & $0.08 \%$ \\
\hline
\end{tabular}

Based on the result, the value of Species Richness Index of macroinvertebrate at tide pools showed high number, although Diversity Index value was below expectation. Macroinvertebrate Dominance Index value indicated that there were dominant species in the tide pools of Batu Kukumbung (Table 5).

\section{Discussion}

In general, abiotic parameter in the study site have supported the existence of organisms to live, except for water temperature. The range of water temperature reached $19^{\circ} \mathrm{C}$ during low tide, which occurred approximately within 4 hours (from 7 to 11 in the morning). The upper limit of water temperature was in accordance with Welch (1992), who made a statement that the temperature could be dangerous to macroinvertebrate if the water temperature ranges from $35-40^{\circ} \mathrm{C}$. The condition of water temperature might affect the abundance and distribution of species inside tide pools.
The ecosystem condition of tide pools in Batu Kukumbung was relatively good, which was indicated by the ecological index. Results of this study also showed that the value of Species Richness Index was high number meaning that tide pools in Batu Kukumbung were in a good environmental status, and attracted many species to live in it. This also indicated that the composition of the species living in the tide pools will not easily alter when environmental disruption appears. Slightly different from species richness, the Diversity Index showed middle value, 2.53 , within the index of the healthy ecosystem range by Shannon-Wiener (1949). This value indicated that the diversity in the tide pools of Batu Kukumbung was not as high as expected $(>3)$ due to its function as a natural reserve area. This result is very much supported by Simpson's Diversity Index, which was close to one, indicated that there were dominant species in the study site.

There are several factors that have possibly affected diversity in the tide pools such as physical factors of the small volume of the habitat, which may restrain the movement of the animal, especially during low tide. The small volume and shallow depth of habitat may also trigger the physical environmental stress condition. High light intensity is directly proportional to the increase in water temperature and accelerated evaporation resulting in the dense of nutrients concentration. As the result of having the ability to adapt to environmental pressure, adaptive species will show high performance in community structure, thus, will also trigger dominance, which was shown in this study. Another possibility was anthropogenic activities around nature reserve areas. It has been reported that people take macroinvertebrate as a food resource, although this might need further investigation on ethnozoology.

Table 4. Fish and coral in the Batu Kukumbung Tidepools, Bojonglarang-Jayanti Nature Reserve, West Java, Indonesia

\begin{tabular}{llcc}
\hline \multicolumn{1}{c}{ Biota } & \multicolumn{1}{c}{ Species } & Ind. & Size range (cm) \\
\hline Fish & Abudefduf notatus Day (1870) & 5 & $3.6-5.2$ (length) \\
& Chromis viridis Cuvier (1830) & 18 & $2.5-3.1$ (length) \\
& Bodianus axillaris E.T. Bennett (1832) & 14 & $4.7-6.8$ (length) \\
& Istigobius decoratus Herre (1927) & 35 & $3.8-5.3$ (length) \\
& & & $9-16$ (diameter) \\
Coral & Favites abdita Ellis and Solander (1786) & 22 & $4-12$ (diameter) \\
& Anthopleura elegantissima Brandt (1835) & 14 & \\
\hline
\end{tabular}

Table 5. Ecological index stated as species richness index, diversity index, and dominance index of macroinvertebrate found in Batu Kukumbung Tidepools, Bojonglarang-Jayanti Nature Reserve, West Java, Indonesia

\begin{tabular}{llll}
\hline Index & Objects & Value & Standards of value \\
\hline Species richness & Tide pools & 6.19 & 4 = good (Jorgensen et al. 2005) \\
Diversity & Gastropods & 2.53 & \\
& Macroalgae & 2.12 & \\
& Fish & 1.33 & $>3=$ good (Shannon-Wiener, 1949) \\
Coral & 0.61 & \\
& & & \\
Dominance & Gastropods & 0.85 & \\
& Macroalgae & 0.33 & \\
& Fish & 0.21 & \\
& Coral & 0.11 & \\
\hline
\end{tabular}


Results in this study also showed that Gastropods were the most frequent species of macroinvertebrates to appear in the tide pools of Batu Kukumbung. These results indicated that this class found adequacy of food and other sources to live in tide pools. Hemminga and Duarte (2000) reported that Gastropods can be carnivore or scavenger, and detritivore of phytoplankton in seagrass as well. However, this result was not in line with the abundance. Although Gastropods were the greatest number of species in Batu Kukumbung, Ophiuroidea was the most abundant, with Ophionereis dubia as the most abundant species overall. Besides generalist feeding (Hendler et al. 2012), Ophiuroidea is cosmopolite and can live either in the sand or among corals. Ophiuroidea can also live in a muddy flat or mixed substrate of sand and mud (Aziz, 1991). Ruppert and Barnes (1994) reported that Ophiuroidea was a class of Echinoderm, which moves a lot in comparison to other classes in Echinoderm so that they can find a shelter to live and hide from environmental disruption (Drolet et al. 2004) including physical disruptions such as excessive light intensities. Aronson (1988) reported that Ophiuroidea has negative phototaxis and are inclined to hide. This cryptic behavior is a consequence of a strong preference for weakly illuminated microhabitats and to a lesser extent for complex substrata (Drolet et al. 2004) and may vary among microhabitat structure (Alexander, 2013). They are also known to have burrowing activities under the sand to avoid high temperature (Sköld, 1998). The ability to hide from the light has become the reason for the abundance of this species in comparison to other macroinvertebrates.

There were four species of Ophiuroidea co-existing in the study site. This result is similar to the one of Boos et al. (2010), stated that Ophiura albida and Ophiura ophiura were co-existing and highly abundant along western European coast. The co-occurrence of four species of Ophiuridae suggested that they had similar ecological requirements and therefore, they were possible to compete for shared resources, especially food and space. This presumably the reason of the dominance of $O$. dubia among the other Ophiuroidea. However, two species cannot possibly realize the same ecological niche (Soberon and Peterson, 2005). Therefore, the co-occurrence of four species of Ophiuridae in the study site indicated ecological differences among species that allow for their co-existence, although, the mechanism for co-existence of species in one class occupied the same habitat and resource which definitely need further study.

The species with the highest Relative Abundance was $O$. dubia, which was also the most abundant and the most frequent in all observed tide pools. The highest value indicated that $O$. dubia had a significant role in the tide pools' food chain. This result also indicated that $O$. dubia was the most adaptive species in terms of temperature and light intensity. This species showed evidence that it can adapt to the wide range of temperature, i.e., up to $18^{\circ} \mathrm{C}$ during the observation. The ability to find shelter on the sidelines of the rock has made it possible for $O$. dubia to avoid light excess in relatively shallow water with $100 \%$ turbidity, as the water temperature increased. The result of Ophiuridae's heat resistance possibly gave support, in terms of temperature, to Hendler et al. (2012) who stated that through asexual and sexual reproduction and antipredation mechanisms, Ophiuroidea is an adaptable invasive species. This cryptic activity kept them in the low body temperature, although this reason might possibly need more study to give better comprehension on physiological response.

During the observation, we also noted other organisms living in the tide pools, such as macroalgae and fish. The existence of macroalgae in the tide pools gave an advantage to macroinvertebrates. Increasing water temperature is causing oxygen depletion in tide pools with limited water volume. With macroalgae inside tide pools, this lack of oxygen condition can be solved. Macroalgae produce oxygen during photosynthesis activities, which is very important when the water temperature increases during low tide. This explains the high number of DO during observation. Macroalgae are also known as shelter provider and food supplier for macroinvertebrates. Intertidal macroinvertebrate and macroalgae occupy low trophic levels and have a quicker response to climate alteration than the species at higher trophic levels (Jenouvier et al. 2003). This was parallel with Godinho and Latufo (2010) who reported that the abundance of macroalgae possibly affects the abundance of macroinvertebrate in tide pools.

The presence of fishes in the tide pools was possibly due to the drifting activities during high tide which made them trapped during low tide. Another possibility was that it was their nursery period since they were all found in juvenile size. Ophiuroidea is one of the food sources for various reef fish species (Sidwell, 2003), and it can be found abundantly in the tide pools of the study site. Birkeland (1989) reported that 33 species of reef fish had Ophiuroidea as a food source. This can explain the existence of fishes in tide pools. The potential predators of ophiuroids are many and include fishes (Packer et al. 1994), decapod crustaceans (Carter and Steel, 1982), and sea anemones (Riedel et al. 2008). This can be another explanation for the presence of a high number of species of Gastropods and reef fish as well.

\section{Conclusion}

In this study, the evidence of water temperature seemed to be the most significant factor in adaptable species. Gastropod showed to be the richest macroinvertebrate species found in the tide pools of Batu Kukumbung, while the most abundant class was Ophiuroidea with the most significant species Ophionereis dubia (Echinoderm). These species indicated certain significant roles in the food chain in the tide pools as well. In terms of the extreme range of water temperature, the high performance of Ophionereis dubia has led this species to become the most adaptive species in the tide pools of Batu Kukumbung.

\section{REFERENCES}

Aziz A. 1991. Beberapa catatan tentang Bintang Mengular (Ophiuroidea) sebagai biota bentik. Oseana 17: 1-9. [Indonesian] 
Alexander TJ. 2013. Cryptic invertebrates on subtidal rocky reefs vary with microhabitat structure and protection from fishing. Mar Eco Prog Ser 481: 93-104.

Aronson RB. 1988. Palatability of five Caribbean Ophiuroids. Bull Mar Sci 43: 93-97.

Birkeland, C. 1989. The Influence of Echinoderm on Coral Reef Communities: Echinoderms Studies. Book Company Inc., New York.

Boos K, Gutow L, Mundry R, Heinz-Dieter F. 2010. Sediment preference and burrowing behaviour in the sympatric brittlestars Ophiura albida Forbes, 1839 and Ophiura ophiura (Linnaeus, 1758) (Ophiroidea, Echinodermata). J Exp Mar Biol Ecol 393: 176-181.

Brower JE, Zar JH. 1977. Field and Laboratory Methods for General Ecology. W.Cm. Brown Co Publisher, Iowa.

Carter JA, Stell DH. 1982. Stomach contents of immature lobsters (Homarus americanus) from Placentia Bay, Newfounland. Canadian J Zool 60: 337-347.

Clark AM, Rowe FWE. 1971. Monograph of Shallow-water Indo-West Pacific Echinoderms. Trustees of the British Museum (Natural History), London.

Celis-Plá PSM, Hall-Spencer JM, Horta PA, Milazzo M, Korbee N, Cornwall CE, Figueroa FL. 2015. Macroalgal responses to ocean acidification depends on nutrient and light levels. Frontier Mar Sci 2: 26. DOI: $10.3389 /$ fmars. 2015.00026

Dharma, B. 2005. Recent and Fossil Indonesian Shells. Coch Books, Hackenheim, Germany.

Drolet D, Himmelmann JH, Rochette R. 2004. Effect of light and substratum complexity on microhabitat selection and activity of the ophiuroid Ophiopolis aculeata. J Exp Mar biol Ecol 313: 139-154

Godinho WO, Lotufo T. 2010. Local v. microhabitat influences on the fish fauna of tidal pools on the north-east Brazil. J Fish Biol 76: 487-501.

Hawkins SJ, Sugden HE, Mieszkowska N, Moore PJ, Poloczanska E, Leaper R, Herbert RJH, Genner MJ, Moschella PS, Thompson RC, Jenkins SR, Southward AJ, Burrows MT. 2009. Consequences of climate-driven biodiversity changes for ecosystem functioning of North European rocky shores. Mar Ecol Prog Ser 396: 245-259

Hemminga MA, Duarte CM. 2000. Seagrass Ecology. Cambridge University Press, London.

Hendler G, Migotto AE, Ventura CRR, Wilk L. 2012. Epizoic Ophiotela brittlestars have invaded the Atlantic. Coral Reefs 31: 1005-1006.
Jenouvrier S, Barbraud C, Weimerskirch H. 2003. Effects of climate variability on the temporal population dynamics of southern fulmars. J Ani Ecol 72: 576-587.

Jorgensen S, Xu FL, Costanza R. 2005. Handbook of Ecological Indicators for Assesement of Ecosystem Health. CRC Press, Florida.

King Z. 2009. Examining Tide Pool Habitats. The Rosen Publishing Group, Inc., New York.

Margalef R. 1968. Perspectives in Ecological Theory. University of Chicago Press, Chicago.

Metaxas A, Scheibling RE. 1993. Community structure and organization of tidepools. Mar Ecol Prog Ser 98: 187-198.

Odum, EP. 1971. Fundamental of Ecology. Third Edition. W.B. Saunders Company, Florida.

Packer DB, Watling L, Langton RW. 1994. The population structure of the brittlestar Ophiura sarsi Lunkten in the Gulf of Maine and its trophic relationship to American plaice (Hippoglossoides platessoides Fabricius). J Exp Mar Biol Ecol 179: 207-222.

Riedel B, Stachowitsch M, Zuschin M. 2008. Sea anemones and brittlestars: unexpected predatory interactions during induced in situ oxygen crises. Mar Biol 153: 1075-1085.

Saito Y, Atobe S. 1970. Phytosociological study of intertidal marine algae. In: English S, Wilkinson C, Baker V (eds) Survey Manual for Tropical Marine Resources. Australian Institute of Marine Science, Townsville, Australia.

Shannon, CE, Weaver, W. 1949. The Mathematical Theory of Communication. University of Illinois Press, Illinois.

Siddwell, M. 2003. The effect of different levels of predation intensity on two populations of Ophionereis schayeri (Ophiuroidea: Echinodermata) in New South Wales, Australia. [Hon. Thesis]. University of Southampton, UK

Simpson, EH. 1949. Measurement of diversity. Nature 163: 688-688.

Sköld M. 1998. Escape response in four epibenthic brittlestars (Ophiuroidea: Echinodermata). Ophelia 49: 163-179.

Soberon, J, Peterson AT. 2005. Interpretation of models of fundamental ecological niches and species' distributional areas. Biodiversity Informatics 2: 1-10.

Welch PS. 1948. Limnological Methods. McGraw-Hill Book Company, New York.

Welch EB, Lindell T. 1992. Ecological Effects of Wastewater: Applied Limnology and Pollutant Effects. Taylor and Francis Group LLC, Washington, DC 